\title{
Banking on industry: the impact of financial services on regional industrial structure and development
}

Citation for published version (APA):

Bos, J. W. B., \& Degl'Innocenti, M. (2018). Banking on industry: the impact of financial services on regional industrial structure and development. Maastricht University, Graduate School of Business and Economics. GSBE Research Memoranda No. 009 https://doi.org/10.26481/umagsb.2018009

Document status and date:

Published: 01/01/2018

DOI:

10.26481/umagsb.2018009

Document Version:

Publisher's PDF, also known as Version of record

\section{Please check the document version of this publication:}

- A submitted manuscript is the version of the article upon submission and before peer-review. There can be important differences between the submitted version and the official published version of record.

People interested in the research are advised to contact the author for the final version of the publication, or visit the DOI to the publisher's website.

- The final author version and the galley proof are versions of the publication after peer review.

- The final published version features the final layout of the paper including the volume, issue and page numbers.

Link to publication

\footnotetext{
General rights rights.

- You may freely distribute the URL identifying the publication in the public portal. please follow below link for the End User Agreement:

www.umlib.nl/taverne-license

Take down policy

If you believe that this document breaches copyright please contact us at:

repository@maastrichtuniversity.nl

providing details and we will investigate your claim.
}

Copyright and moral rights for the publications made accessible in the public portal are retained by the authors and/or other copyright owners and it is a condition of accessing publications that users recognise and abide by the legal requirements associated with these

- Users may download and print one copy of any publication from the public portal for the purpose of private study or research.

- You may not further distribute the material or use it for any profit-making activity or commercial gain

If the publication is distributed under the terms of Article $25 \mathrm{fa}$ of the Dutch Copyright Act, indicated by the "Taverne" license above, 
Jaap W.B. Bos,

Marta Degl'Innocenti

Banking on industry: the impact of financial services on regional industrial structure and development

RM/18/009

\section{GSBE}

Maastricht University School of Business and Economics

Graduate School of Business and Economics

P.O Box 616

NL-6200 MD Maastricht

The Netherlands 


\title{
Banking on industry: the impact of financial services on regional industrial structure and development
}

\author{
By JaAp W.B. Bos, Marta Degl'INNOCEnTi *
}

We investigate the extent to which local banking market characteristics can explain where small enterprises (SES) are located and how they thrive. We start from a simple theory that explains the channels along which local banking market structure can affect the growth of SEs. Subsequently, we make use of a highly detailed data set, exploit unique features of the Italian banking system and find that the structure of the banking system explains the regional distribution of SEs in Italy, in particular through the historical presence of small banks.

JEL: G21, R11, C21, D40

Keywords: SMEs, Banking, Market Structure

\section{Introduction}

Small Enterprises (SEs) tend to have a complex relationship with the banks that provide them with loans. Not only do they rely on bank loans for financing new investment, but in addition their (lack of) size often makes them opaque and ill-fitting for the 'cookie cutter' process with which large financial institutions assess their loan applications (Cole, Goldberg and White, 2004). There are more than 20 million SEs in the EU, representing 99 percent of all businesses. SEs are the propulsive engine of European economic growth, alleviating poverty (Beck, Demirguc-Kunt and Levine, 2005).

But where are they located? How do they thrive? Who finances their investments? In this paper, we contribute to providing answers to these questions, by focusing on one important, but often overlooked, ingredient in the success formula for SEs: the existence of small banks. We study the relationship between the share of small banks in a local market and the share of SEs in that same market.

Small banks may be crucial to the survival of small businesses, since they may be better at managing soft information, collected via personal interaction and difficult to codify. In contrast, large, hierarchically organized banks may experience more organizational frictions in lending to small borrowers, especially if the latter are opaque and/or innovative (Peek and Rosengren, 1995; Berger and Udell, 2002; Berger et al., 2005; Liberti and Mian, 2009; Alessandrini, Pres-

\footnotetext{
* Bos: Maastricht University School of Business and Economics, P.O. Box 616, 6200 MD, Maastricht, The Netherlands, j.bos@maastrichtuniversity.nl. Degl'Innocenti: corresponding author, Southampton Business School, University of Southampton, Southampton, UK, m.deglinnocenti@soton.ac.uk. The usual disclaimer applies.
} 
bitero and Zazzaro, 2010). Furthermore, large banks may have the upper hand in lending to small, opaque SEs through their use of transaction technologies that process hard information in more efficient, novel ways (Berger and Udell, 2006; De la Torre, Pería and Schmukler, 2010; Berger and Black, 2011).

We contribute to this stream of research by exploring the relationship between the location of small banks and the numbers and distribution of SEs in local markets. Our 'laboratory' for doing so is Italy, which has the largest number of SEs in the EU with 3.813 million SES with less than 10 employees. SEs contribute $29.5 \%$ of value-added $(21.2 \%$ for the EU-28) and $46 \%$ of employment (EU-28: $29.5 \%$ ). Almost of $11 \%$ of the SEs in manufacturing are engaged in high- or midto-high-tech activities, in line with the European average (EU-27: $12 \%){ }^{1}$

Importantly, for Italy we can make smart use of two consecutive regulatory changes. In 1936, the Italian government imposed a strictly entry regulation in order to enhance bank stability by limiting bank competition through constraints to the opening of new banks and branches. From then on, the opening of a new branch was subject to strict controls and required explicit authorization by the Bank of Italy. Consequently, local banking markets in Italy became indeed very 'local.' That status quo persisted until 1987, when the Single European Act became effective in Italy, invalidating the earlier constraints and eventually resulting in an increase in the number of branches in Italy from 17,721 in 1990 when the law indeed was repealed - to 34,146 in 2008 (Benfratello, Schiantarelli and Sembenelli, 2008). Consequently, the structure of the Italian banking system in this period is generally considered to be unrelated to the regional economic development of the time (Guiso, Sapienza and Zingales, 2004; Herrera and Minetti, 2007; Benfratello, Schiantarelli and Sembenelli, 2008; Alessandrini, Presbitero and Zazzaro, 2009, 2010; Ferri and Murro, 2015).

Therefore, in order to study the causal impact of small bank market share on the share, location and distribution of SEs, we build an identification strategy based on branch level banking data from both 1936 and 1987, respectively. We find that, over the period 1998-2013, approximately 24 percent of the variance in the local market share of SEs can be attributed to the (historical) presence of small banks.

To explore the channels along which this presence of small banks affects SEs, we built on the work of Boot and Thakor (1997) and introduce a simple model of financial system architecture, where large multi-market banks are informed agents and local unitary banks function as monitoring agents, very much in line with the 'cookie cutter versus character' premise of Cole, Goldberg and White (2004) and others. From the model, we can derive a number of conditions that would allow SEs to thrive through the presence of small banks. Our highly disaggregated Italian data then allow us to test each of these channels.

From these tests, a clear picture emerges of the small banks-SEs financing link. SEs need small banks in a (local) economy that is relatively weak, and can thrive

\footnotetext{
${ }^{1}$ Source: 2016 SBA fact sheet for Italy.
} 
through the financing they receive from these banks in the absence of very large, dominant banks, if there is enough competition among banks in the local market and if small banks can provide high quality loan monitoring, by being large enough and employing high-quality personnel. SEs that thrive in particular through the presence of small local banks are relatively risky, often financially fragile and may have an opportunity to capture private rents from borrowing. Furthermore, we verify whether our results are driven by the innovativeness of SEs, rather than their size. Finally, we explore what the Italian manufacturing sector would look like without the liberalization process of 1990.

We are of course not the first to identify the causal relationship between the development of the Italian banking sector and the share of SEs using the 1987 (and 1936) regulatory changes. Recent related work has for example focused on the roles of bank branch density (Benfratello, Schiantarelli and Sembenelli, 2008), the functional distance of the local banking system (Alessandrini, Presbitero and Zazzaro, 2009), and bank-firm ties (Herrera and Minetti, 2007; Ongena, Tümer-Alkan and Westernhagen, 2012; Giannetti, 2012). Hakenes et al. (2015) investigate the effect of small banks and big banks on promoting local economic growth. They find that the presence of savings banks as regional funding providers boosts the local economic growth, especially in relatively poor regions.

The contribution of this paper is threefold. First, we identify the channels through which the banking sector and economic environment can facilitate the creation and accumulation of SEs in a specific region. Second, we provide novel evidence on how and to what extent the configuration and geographical organization of the banking industry affects the features of the regional industrial sector. Third, we identify further economic local factors that can affect the configuration of the regional industrial sector.

The structure of the paper is as follows. Section II discusses the theoretical model and identification strategy. Section ?? describes the database. Section IV presents the empirical findings. Section V concludes and outlines the directions for further research.

\section{The impact of banking structure on local industrial structure}

To investigate the impact of local banking structure on local industrial structure, in particular the share of SEs, we follow an approach that consists of three, related parts. First, we develop a straightforward identification strategy to establish the causal effect of local banking market structure on the local presence of SEs. Second, we build on Boot and Thakor (1997) and develop a model that allows us to make out the channels along which this causal effect materializes. Third, we demonstrate how our identification strategy, together with our theoretical model results in an empirical test of the impact of banking structure on local industrial structure. 


\section{A. Identifying causality}

Our first task is to ensure we can identify the causal impact of local banking structure on local industrial structure. To do so, we need three things.

First and foremost, we need to exclude endogeneity concerns. As explained above, the tight regulation of the Italian banking market prior to the period under investigation in this paper helps a great deal (Guiso, Sapienza and Zingales, 2004; Herrera and Minetti, 2007; Benfratello, Schiantarelli and Sembenelli, 2008; Alessandrini, Presbitero and Zazzaro, 2009, 2010; Ferri and Murro, 2015). In our empirical analysis, we therefore make use of two sets of measures of local banking structure: one set consists of the market share and number of branches of local banks for each of Italy's 103 NUTS3 regions in 1936, when the law that for a long time limited geographical expansion became effective. The other set measures the same, but now for 1987, just before the removal of the law. We later show that in the period in between 1936 and 1987, the Italian banking sector was indeed highly stable, further strengthening our identification strategy.

Figure 1. : Identification

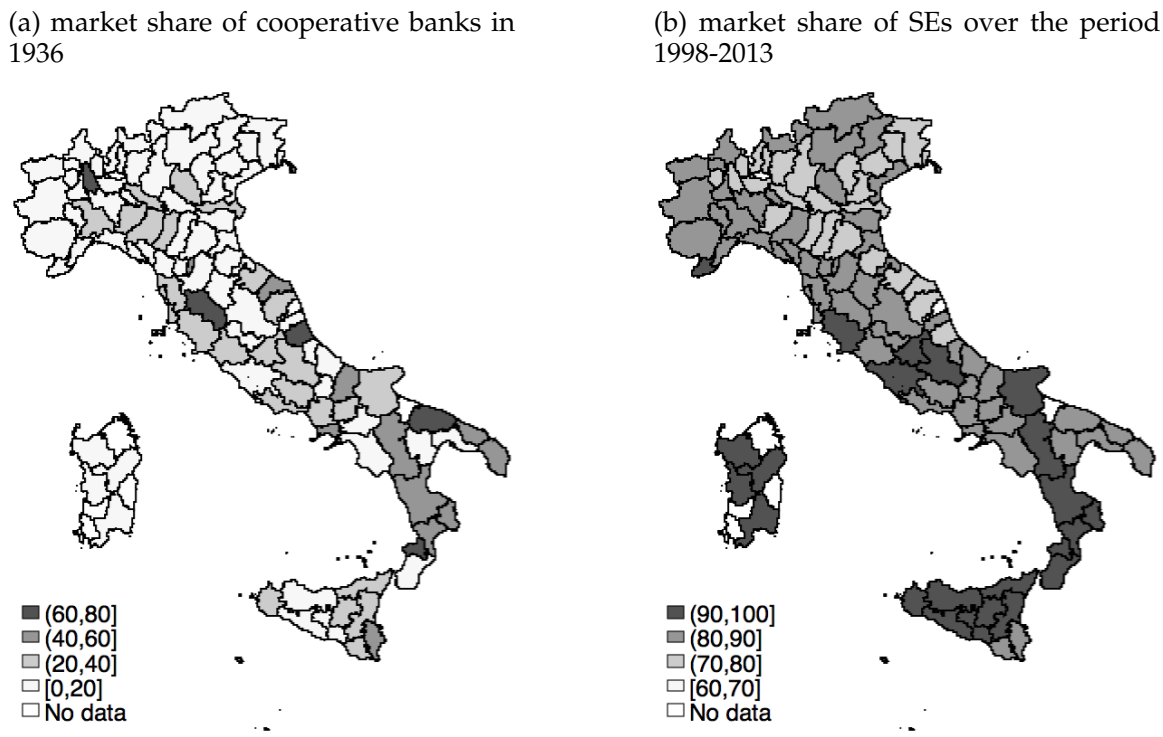

Note: The market share of cooperative banks has been calculated as the ratio of the cooperative banks divided by the total banks in each NUTS3 region in 1936. The market share of SEs is calculated as the average number of manufacturing firms with less than 10 employees divided the average number of all manufacturing firms at the NUTS3 level over the period 1998-2013.

Second, we exploit the institutional composition of the Italian banking sector. Lending to small, often relatively opaque borrowers, is a skill that some banks are more likely to master than others. On the one hand, advances in the use of 
information technology to process hard information in lending have arguably decreased the importance of physical proximity in lending (Petersen and Rajan, 2002). On the other hand, soft information continues to be a driver of relationship lending (Bartoli et al., 2013; Petersen and Rajan, 1994), something large institutions typically do not excel at (Ferri and Murro, 2015; Peek and Rosengren, 1995). Moreover, gathering soft information is a costly and difficult to monitor investment for local loan officers and can generate agency and incentive problems, in particular in complex, hierarchically organized banking organizations (Alessandrini, Presbitero and Zazzaro, 2010; Berger et al., 2005). In the context of the Italian banking market, therefore, we pay particular attention to the role played by small cooperative banks. For 133 years, since the start of the so-called Credito Cooperativo system, Italian cooperatives have been local, mutual and non-profit. They exist all across Italy and claim to maintain values and an identity that enables them to provide a service to the local community that is particularly important for the firms we are interested in here. Hence, we focus on the market share and number of branches of cooperative banks in our analysis.

Third, we need geographical and time variation, for both the local industrial structure and the local banking market structure (post deregulation). After the deregulation process in the early 90 s the structure of the local banking system has changed profoundly as the number of branches increased exponentially. In addition, the Italian banking market went through an intensive process of mergers and acquisitions, resulting in a decrease of the number of banks from more than a thousand to less than 800 , although banking groups are still relatively small compared to international competitors (Bank of Italy, 2014). Meanwhile, the number of firms with less than ten employees declined with $25.78 \%$ in the period 1998-2013. ${ }^{2}$

Figure 1 provides a snapshot of the geographical variation. From the figure, we can make two observations regarding the Italian banking sector. First, we see that small banks are relatively important in various NUTS3 regions, both in the south (e.g., the regions of Sicily, Calabria, Basilicata) and in the centre and north (e.g., Tuscany, Lazio, Liguria). Second, we observe that the - historical - share of cooperative banks coincides with a strong presence of SEs (with the exception of NUTS3 regions in Sardegna, in Emilia-Romagna and Marche). SEs abound in the south of Italy and on the islands, but are also plentiful in other NUTS3 regions of the centre (Toscana, Umbria, Abruzzo) and north (TrentinoAlto Adige, Valle d'Aosta). Large firms are mostly located in the NUTS3 regions of Piemonte, Emilia Romagna, Lombardia, Friuli-Venezia Giulia.

Now that we have gathered enough data to explore the causal impact of local banking structure on local industrial structure, we proceed one step further. After all, at a time when the small, local bank is - for reasons ranging from technological progress, scale economies to empire building and deregulation - increasingly at the fringes of the financial landscape, it is worthwhile finding out

\footnotetext{
${ }^{2}$ Source: ISTAT Asia database.
} 
just what makes these particular banks play an important role in shaping our local economies. In order to find out more, in the next subsection, we put our own twist on an established theory of financial system architecture to see if it can help us identify the channels along which small, local banks can be of importance for SEs.

\section{B. Identifying channels}

In order to really understand the way access to financing from small local banks affects the fate of SEs in the same area, we need a more refined perspective. To get this perspective, we build on the work of Boot and Thakor (1997) and introduce a model that explains the selection process by which borrowers of different sizes are matched up with large and small banks. For firms, the key role size plays in this matching process is that it affects the ability to credibly signal (credit) quality. For banks, the key role of size is its impact on the extent to which (credit) risks can be diversified, and therefore managed in the decision to extend credit (or not).

\section{WHY SHOULD SES BORROW FROM SMALL BANKS?}

Banks of all sizes in the end have the same objective: to fund all firms that constitute a positive net present value (NPV) for them. And banks of all sizes face, to a large extent, the same amount of asymmetric information. Size, however, determines what is the optimal strategy for a large and a small bank, respectively. Whereas a large bank can use scale (in monitoring, and otherwise) to employ a 'cookie cutter' approach to lending that minimizes adverse selection by screening borrowers, a small bank resorts to relationship lending and monitoring to minimize moral hazard. Both approaches require a substantial investment: whereas large banks have to invest in gathering and processing hard information, small banks do the same with soft information. Consequently, banks tend to specialize in either approach. Since there are scale economies in the former, it is favored by large banks.

Along the same lines, a large firm that has a credit history and outside alternatives (e.g., capital markets) will try to signal the quality of its projects to secure a loan at a reasonable prices. At the same time, a SE that is opaque, has little or no credit history and may engage in innovative (and risky) projects, cannot signal its credit quality credibly yet, if it selects the right projects, is willing to subject itself to ex-post monitoring.

The result then is a pairing of firms and banks that is very much in line with Cole, Goldberg and White (2004), who find evidence of the coexistence of 'cookie cutter' and 'character' and for a US setting show that borrowers select banks just like banks select borrowers. 
In line with Boot and Thakor (1997), we start by introducing three aspects of asymmetric information. ${ }^{3}$ First, there is incomplete information about future projects that is of relevance for firm valuation and firms' investment decisions. Second, there is the risk of ex-post asset substitution moral hazard that can affect payoffs to banks. Third, there is uncertainty about the extent to which moral hazard plays a role in borrowers' decisions.

Borrowers choose between a good project and a bad project, both requiring an investment of one, supplied by a bank. For the bank, the risk of lending consists of three, related elements. The first element is the nature of the project. For a good project, the payoff is $Y$ with probability $\eta$, and 0 with probability $1-\eta$. For a bad project, the payoff is always 0 , but firms receive a private rent $N$ that is less than $\eta Y$, and is thereby less attractive to banks, even if they manage to deprive firms of these private rents.

The second element is asymmetric information between firm and bank, which determines the room firms have to make (bad) project decisions. In the lowflexibility state, firms can only choose good projects, whereas in the highflexibility state firms have the option of choosing a bad project. Each firm finds itself in a low flexibility state with probability $\theta$ and in a high flexibility state with a probability $1-\theta$, where $\theta \in(\bar{\theta}, \underline{\theta}) \subset(0,1)$.

The third element is idiosyncratic risk, which takes the form of a firm-specific realization of an environmental variable $v(0,1)$. It is the value of $v$ that connects the project risk with the degree of asymmetric information and affects the borrowing choice. In essence, the realization of $v$ can provide firms with the resources to signal their project choice. This matters, since $Y|v=1>Y| v=0 .{ }^{4}$

It is therefore in the interest of banks for firms to choose the good project (if they can choose the bad project as well), and to exert extra effort with good projects. If banks can be sure enough that firms make these decisions, lending to these firms is a healthy business for them.

\section{THE ROLE OF SIZE}

That brings us to the core of this part of our analysis: whether and how banks manage to ensure that firms make these decisions depends on the size of firms and the size of banks.

The role of the size of firms is fairly straightforward: at the outset, the degree of asymmetric information is much higher when lending to SEs than it is when

\footnotetext{
${ }^{3}$ Throughout, we shall follow their notation, unless indicated otherwise.

${ }^{4}$ To see why that is the case, consider that in Boot and Thakor (1997), if $v=1 \mathrm{a}$ firm can enhance the payoff of a good project by exerting extra effort $K=\bar{K}$ where $K \in\{0, \bar{K}\}$. Once the firm does this, a good project will have a payoff of $Y+\alpha$ with a probability $\eta$, and a payoff of $\alpha$ with a probability $1-\eta$, where the realization of $\alpha \in(0,1)$ depends on $v$. There is a catch, of course: if the project is not successful, the firm is faced with a debt overhang problem, since $\alpha \prec 1$.
} 
lending to large firms (Beck, Demirgüç-Kunt and Maksimovic, 2008; Berger and Udell, 2006; Ferri and Murro, 2015).

The role of the size of banks is more complex. To understand that role, we first need to understand the tools banks have at their disposal to deal with asymmetric information in the lending process. We focus on two tools, each aimed at minimizing a specific type of risk associated with asymmetric information.

The first tool is selection. When attempting to minimize adverse selection, banks can try to learn more about the firms that approach them for a loan by investing an amount $M>0$. By spending $M$, these banks learn about the realization of $v$, which provides them with crucial information to make a better loan offer to firms with a $v=1$, and thereby selecting more of these firms as their borrowers, instead of firms with $v=0$. In the original terminology of Boot and Thakor (1997), these banks are now informed agents. The informational advantage they have allows them to induce - through selection - firms to exert effort when they should.

The second tool is monitoring. Banks can also spend $M>0$ on monitoring firms after they have granted them a loan. By monitoring firms, banks can force firms to choose good projects when they should. The bank expects the following profit on the loan.

$$
\theta \eta \frac{\left[1+\lambda^{*} M\right]}{\eta}-1=\theta\left[1+\lambda^{*} M\right]-1<0,
$$

which in turn implies that it is convenient for a bank to invest in monitoring and screening activities since an unmonitored project has a negative net present value (NPV) $(1-\theta) \eta Y \prec 1$, while a monitored project has an NPV $\succ 0, \eta Y \succ$ $1+\lambda^{*} M$.

Summing up, banks can play a role in both aspects that improve borrowing firms' project outcomes. However, a single bank cannot improve its selection and its monitoring. One reason for this is very intuitive: this would require an investment of $2 \times M$, which would result in a loan rate that can easily be undercut by some banks, who cater to specific types of firms (for example, large firms with less asymmetric information who can credibly signal and therefore pose no risk of adverse selection).

More relevant for the purpose of our analysis, the optimal bank size for both tools is likely to be different. The minimum measure of monitoring agents needed to deter the borrower from selecting a bad project is $\lambda^{*}<1$. In order to ensure the collective of monitoring agents is devoid of free riding, its maximum feasible size is also limited.

Does the same hold for selection? Recall that selection is done based on $v$. Neither firm nor bank knows $v$ before its realization and (for the bank) investing $M$, although the firm knows the probability $\gamma$ that $v$ will be 1 . However, contrary to the monitoring process, where banks cannot spread moral hazard risk by diversifying, a bank that tries to lower adverse selection might be able to lower 
risk by diversifying - in particular if it can learn about $v$ by dealing with similar borrowers and projects in different markets.

A picture of two sizes of banks emerges, based on this analysis of bank lending. One is a small bank that opts for monitoring relies on soft information, and as Petersen and Rajan (2002) argue, is likely to be a local lender who collects soft information on SEs over time and has an informational advantage over more remote competitors who might not have the access to the same degree of local information. The other is a large bank who is active on multiple markets, relies on hard information and opts for a selection strategy.

What remains then, is a formal matching that shows why and when a small (large) firm should opt for a small (large) bank when applying for credit.

\section{CHANNELING FUNDS FROM BANKS TO FIRMS}

Still putting our own spin on the financial system architecture described by Boot and Thakor (1997), it is now time to put the pieces of the puzzle together and find out what may connect small, local firms to small, local banks. In what follows, we compare the cost of borrowing from a small, local bank to the cost of borrowing from a large, multi-market bank. In doing so, we rely on a mechanism that is explained in more detail in Boot and Thakor (1997): large firms with a good project can signal their worthiness to banks in a way that is not replicable to others (including SEs, even if they have a good project). However, SEs with a good project survive the monitoring banks subject them to.

The final piece of the puzzle then lies in the difference between a firm's ex ante signaling and a bank's ex post monitoring: whereas the signaling is done by a single firm, the monitoring is done by a bank, a coalition of monitoring agents. Hence, whereas both the signaling and the monitoring require a minimum investment, the monitoring also has its upper limits: a coalition (i.e., bank) that is too large is too vulnerable to free riding. The end result is a situation where small, local firms borrow from small, local banks, and large firms borrow from large, multi-market banks.

To see how we arrive at this result, we start by establishing, from the model so far, the expected loan interest rate for a small, local bank. ${ }^{5}$ Before we do so, we introduce one more element into the model: we assume that the small bank can prevent the choice of bad projects only with a probability $\xi$. In that case, if the small bank earns zero profits, it charges: ${ }^{6}$

$$
i_{S}=\frac{\left(1+\lambda^{*} M\right)}{\eta[\theta+\{1-\theta\} \xi]},
$$

\footnotetext{
${ }^{5}$ From this point onwards, we occasionally change our notation from Boot and Thakor (1997). More importantly, in our take on their model, a large, multi-market bank, is effectively placed in between the financial institution in their model and the financial market.

${ }^{6}$ Equation (2) follows from the fact that $i_{S} \eta[\theta+\{1-\theta\} \xi]=1+\Lambda^{*} M$.
} 
which covers the monitoring cost $M$ incurred by a bank in the post-lending stage, and is lower if the risk of moral hazard is low ( $\xi$ is high) and it is likely that the firm will do well ( $\eta$ is high).

The expected return, $E(R)$, to the borrower of proceeding with the project depends on whether the borrower gets a loan from a small bank or from a large bank:

$$
\begin{aligned}
& E\left(R_{S}\right)=[\theta+\{1-\theta\} \xi] \eta\left[Y-i_{S}\right]+[1-\theta][1-\xi] N \\
& E\left(R_{L}\right)=\theta\left\{(\gamma) E\left(R_{L} \mid v=1\right)+(1-\gamma) E\left(R_{L} \mid v=0\right)\right\}+(1-\theta) N
\end{aligned}
$$

where $E\left(R_{L}\right)$ is the unconditional expected return from borrowing from a large bank, and $E\left(R_{S}\right)$ is the unconditional expected return from borrowing from a small bank. At this point remember that small, opaque borrowers below a threshold value $\bar{\theta}$ of observable quality opt for small bank financing, and borrowers above that threshold value choose large bank financing. Hence, the higher $\bar{\theta}$, the more the presence of SEs depends on the availability of small bank financing. To see how $\theta$ depends on the market share of small banks $\sigma_{s}$, we proceed by combining equations ( $3 a$ ) and ( $3 b$ ) and following the derivations in the Appendix obtain:

$$
\begin{aligned}
\theta= & \sigma_{S}\left\{\frac{E\left(R_{S}\right)-\xi \eta\left(Y-i_{S}\right)-(1-\xi) N}{\eta\left(Y-i_{S}\right)-\xi \eta\left(Y-i_{S}\right)-(1-\xi) N}\right\}+ \\
& \left(1-\sigma_{S}\right)\left\{\frac{E\left(R_{L}\right)-N}{\gamma E\left(R_{L} \mid v=1\right)+(1-\gamma) E\left(R_{L} \mid v=0\right)-N}\right\}
\end{aligned}
$$

Therefore:

(5)

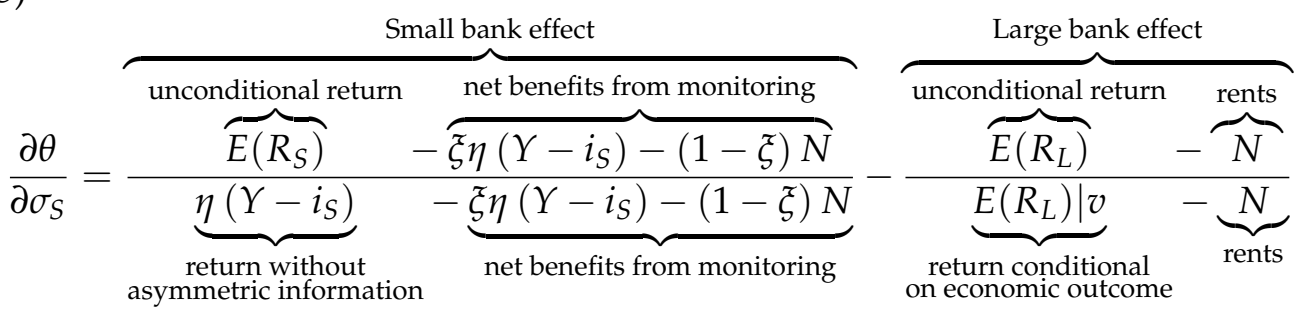

where $E\left(R_{L}\right) \mid v=\gamma E\left(R_{L} \mid v=1\right)+(1-\gamma) E\left(R_{L} \mid v=0\right)$.

Equation (5) is the core of our approach to identifying the channels along which the presence of small banks affects the fate of SEs. Recall that a lower threshold value for $\theta$ implies that there is a high probability that a firm finds itself in a high flexibility state, where it may depend on a small bank that monitors for financing. Then consider the two ratios that make up the right-hand side of equation (5).

The first ratio determines the relative need for small bank financing. As is to be expected, the dependence on small banks increases with the unconditional 
expected return from borrowing from small banks $\left(E\left(R_{S}\right)\right)$. If asymmetric information is no issue, an increase in $\eta\left(Y-i_{S}\right)$ ensures that the dependence on small banks decreases. Since $0 \leq \theta \leq 1$, we know from equation (A.1a) that $E\left(R_{S}\right) \leq \eta\left(Y-i_{S}\right)$. Therefore the small bank effect is decreasing in the net benefits (to the bank) from monitoring. Those benefits themselves increase in the probability of preventing a bad project $(\xi)$, requiring additional monitoring costs $(M)$ and boosting monitoring capacity $(\lambda) .{ }^{7}$ If rents $(N)$ increase, net monitoring benefits decrease, lowering the likelihood of obtaining a loan from small banks. Likewise, if the payoff $(Y)$ for a good project increases.

The second ratio determines the relative need for large bank financing. As is the case for small banks, higher rents decrease the likelihood of obtaining a loan from large banks. The effect is even stronger here, since large banks cannot prevent high-flexibility borrowers from engaging in riskier projects to pursue private rents. At the same time, the bigger the difference between the offer a large bank can make, based on the signal it received, to firms in a good state $(v=1)$ and the unconditional offer, assuming the bank cannot use this information, the more large banks will be able to steal borrowers from small banks, thus lowering the latter's share of the market.

Of course, each borrowing firm, large or small, should take a loan from the bank where the expect return that this firm makes on its investment financed with this loan is the highest. Table 1 summarizes how equations (3a) and (3b) inform us about the factors that affect the likelihood that a (good) SE borrows from a small bank.

\section{Empirical strategy}

Now that we have developed our identification strategy and have introduced the factors that can strengthen the impact the presence of small banks has on the share of SEs in a NUTS3 region, it is time to discuss our empirical strategy. We can test for the impact of the presence of small, local banks with the following two specifications:

$$
\begin{aligned}
& M S_{i t}^{S E}=b_{0}+b_{M S^{S B, 1936}} M S_{i}^{S B, 1936}+\gamma C^{\prime}+\varepsilon_{i t} \\
& M S_{i t}^{S E}=b_{0}+b_{M S^{S B, 1936}} M S_{i}^{S B, 1936}+b_{X} X_{i t}+b_{X} M S_{i}^{S B, 1936} \times X_{i t}++\gamma C^{\prime}+\varepsilon_{i t}
\end{aligned}
$$

where $M S_{i t}^{S E}$ is the market share of small firms in NUTS3 region $i$ at time $t$, $M S^{S B, 1936}$ is the historical market share (in 1936) of small banks in the same region at the same time, $X_{i t}$ is as vector of variables that follows directly from our discussion of the channels through which the latter affect the former, and $C^{\prime}$ is a vector of demand-side control variables that can explain the number of new and existing small businesses. In particular, we include the level of resident population in each NUTS3 region as suggested by Keeble and Walker (1994), as well as

\footnotetext{
${ }^{7}$ To see why, refer to equation (2).
} 
a variable to measure the geographical size of each NUTS3 region to control for the potential degree of spatial concentration of local markets.

Equation (6a) follows directly from our identification strategy: $b_{M S^{S B, 1936}}$ measures the impact of (historical) small bank presence on the market share of SEs in a NUTS3 region. From equation (6b), we can infer the channels along which the former affects the latter, i.e., $\partial M S_{i t}^{S E} / \partial M S_{i}^{S B, 1936}=b_{M S^{S B, 1936}}+b_{X} X_{i t}$. As a result, the full model is as follows:

$$
\begin{aligned}
& M S_{i t}^{S E}=\beta_{0}+\underbrace{\beta_{M S_{i}^{S B, 1936} M S_{i}^{S B, 1936}}}_{\text {Identification [+] }}+\underbrace{\beta_{M S_{i}^{S B, 1936} \times \theta} M S_{i}^{S B, 1936} \times \theta}_{\text {Project choice [-] }}+ \\
& \underbrace{\beta_{M S_{i}^{S B, 1936} \times v} M S_{i}^{S B, 1936} \times v}_{\text {Performance [-] }}+\underbrace{\beta_{M S_{i}^{S B, 1936} \times R^{M}} M S_{i}^{S B, 1936} \times R}_{\text {Loan rate }[+/-]}+ \\
& \underbrace{b_{M S_{i}^{S B, 1936} \times N} M S_{i}^{S B, 1936} \times N}_{\text {Private rent [-] }}+\underbrace{\beta_{M S_{i}^{S B, 1936} \times \lambda} M S_{i}^{S B, 1936} \times \lambda}_{\text {Minimum size [-] }}+
\end{aligned}
$$

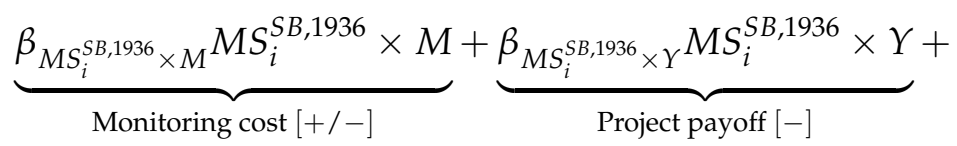

$$
\begin{aligned}
& \underbrace{\beta_{M S_{i}^{S B, 1936} \times \eta} M S_{i}^{S B, 1936} \times \eta}_{\text {Chance of success [-] }}+\varepsilon
\end{aligned}
$$

In the next section, we describe in more detail how we measure each of the items included in Equation (7).

\section{Data}

\section{A. SEs and small banks}

We start with a description of our two key variables of interest. First, we discuss the presence of small enterprises. Then, we explain how we account for the historical presence of small banks.

We measure $M S_{i t}^{S E}$ in several ways. First, we use $M S_{i t}^{S E, \text { micro }}$ to account for the share of micro manufacturing firms, calculated as the ratio of firms with less than 10 employees divided by the total number of manufacturing firms for each year and NUTS3 region. ${ }^{8}$ Second, we use $M S_{i t}^{S E, s p}$ to account for the share of sole proprietorship firms in the same manner. Since for these firms the entrepreneur is the owner and personally liable when the firm suffers losses, private rent issues can be more severe than for other types of firms. Taken together, these firms account on average for about 55 percent of all firms in manufacturing in Italy. ${ }^{9}$

\footnotetext{
${ }^{8}$ Source: https://www.bancaditalia.it/compiti/vigilanza/albi-elenchi/index.html.

${ }^{9}$ Source: ISTAT Asia database.
} 


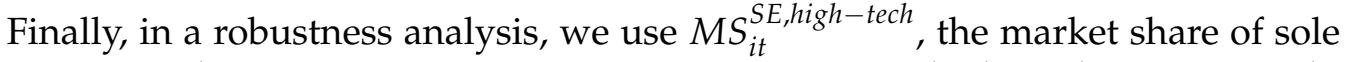
proprietorships active in innovative sectors, to assess whether what we are picking up is indeed the size effect of SEs rather than the fact that these may be the most innovative firms. ${ }^{10}$

Important for our analysis, the 1936 banking law attributed a specific geographical area of competence to each type of credit institution (Minetti, Murro and Paiella, 2015). In particular, cooperatives banks could only open branches in the NUTS3 regions where they were already present in 1936. In contrast, saving banks could expand within the regional boundaries where they operated in 1936 (NUTS2 level), while national banks were allowed to open branches in the main cities. Cooperative banks are small and focused on local markets and they lend themselves well for our research hypothesis. For $M S_{i}^{S B, 1936}$, we take the market share of cooperative banks in 1936, defined as the number of cooperative banks divided by the total number of banks. As an alternative, we use $M S_{i}^{S B, 1987 \text {, }}$ the share of of cooperative banks in 1987, just before the 1936 banking law was renounced. ${ }^{11}$

\section{B. Channels and additional control variables}

To capture the different channels along which the presence of small, local banks can have an impact on the share of SEs, we need to proxy each of the different elements we introduced before. We describe our approach for each of the channels in Table (1). As control variables, we take into account the population and geographical dimension of each NUTS3 region. In particular, Pop is the logarithm of the population in each NUTS3 region and Area is the logarithm of $K M^{2}$ per NUTS3 regions.

Of all the channels, the one that requires a more elaborate explanation is the cost of borrowing, $R$. We measure $R$ by using a measure of competition. In particular, we make use of the Lerner Index which measures the extent to which banks in a region $i$ at time $t$ are able to set a price $\left(P_{i t}\right)$ above their marginal cost $M C_{i t}$ :

$$
R_{i t}=\left(P_{i t}-M C_{i t}\right) / P_{i t}
$$

where $M C_{i t}$ is calculated from a translog cost frontier estimated at the NUTS3 level, with a single output, loans, two input prices (deposit and labor) and a trend variable to capture technological progress. ${ }^{12}$ In estimating the translog cost

\footnotetext{
${ }^{10}$ Following Ughetto (2008), we classify a firm as a high-tech firm if it belongs to the following industrial sectors: chemicals and drugs (Ateco 24), mechanical machinery (Ateco 29), computer equipment (Ateco 30), electronic components and machinery (Ateco 31), communication equipment (Ateco 32), medical, optical, and precision equipment (Ateco 33), and transportation equipment (Ateco 34-35). Source: ISTAT: Asia database; Infocamere: Movimpresa.

${ }^{11}$ Unfortunately, the available data do not allow us to measure the market share based on total assets or total loan volume.

${ }^{12}$ We estimate a fixed effects frontier model, with a time varying decay for the inefficiency term and regional
} 
Table 1—: Should a good SE borrow from a small bank?

\begin{tabular}{|c|c|c|}
\hline \multicolumn{2}{|c|}{ Variable (effect) } & Explanation \\
\hline$\theta(-)$ & $\begin{array}{l}\text { Probability of a } \\
\text { low flexibility } \\
\text { state }\end{array}$ & $\begin{array}{l}\text { Since a large bank can observe bor- } \\
\text { rower's initial choice, probability } \\
\text { that its borrower will invest in bad } \\
\text { project is lower. }\end{array}$ \\
\hline$v(-)$ & $\begin{array}{l}\text { Environmental } \\
\text { variable }\end{array}$ & $\begin{array}{l}\text { Reflects the capability of repaying } \\
\text { the loans received from a bank. }\end{array}$ \\
\hline$R(+/-)$ & $\begin{array}{l}\text { Cost of bor- } \\
\text { rowing }\end{array}$ & $\begin{array}{l}\text { Large banks can promote competi- } \\
\text { tion in retail loans because of the } \\
\text { access to low-cost wholesale funds. } \\
\text { As a result, consumer loan rates de- } \\
\text { crease as the large bank's shares in- } \\
\text { crease (Park and Pennacchi, 2009). } \\
\text { Based on this view, the presence of } \\
\text { large banks could promote compe- } \\
\text { tition. On the other hand, large } \\
\text { banks compete with each other si- } \\
\text { multaneously in more than one ge- } \\
\text { ographical and/or product market. } \\
\text { The number of markets shared by } \\
\text { banks may foster incentives for tacit } \\
\text { collusion, thereby weakening com- } \\
\text { petition (Edwards, 1955). }\end{array}$ \\
\hline
\end{tabular}

$N(-) \quad$ Private rents Likely to be high as the opacity of borrowers increases and it is difficult to monitor and measure its outputs.

Reduction of asymmetric information between borrower and lender. In these circumstances, a SE is more likely to get funds also from a large bank.

$M(+/-) \quad$ Monitoring and information acquisition cost

$Y(-) \quad$ Successful project payoff $\eta(-) \quad \begin{aligned} & \text { Probability of a } \\ & \text { good payoff }\end{aligned}$
For small banks, an increase in $M$ increases monitoring costs, for large banks it increases the information acquisition cost.

Related to the profitability of borrowers. If a project has a high payoff, it is more likely that a SE will get funds from a large bank

A measure of the performance of the industrial sector, which can affect the probability of a borrower repeating the performance during the next period.
Measurement

Market share of medium-large banks in each NUTS3 region, calculated as the ratio of the number of their branches (or banks) divided the total number of branches (or banks) in the same NUTS3 regions.

The ratio of the growth of employees of SEs in manufacturing for each NUTS3 region to the total growth of the employees in manufacturing at the NUTS3 level.

The Lerner Index to measure the local market competition in the loan market (see equation 8).

The market share of high-tech manufacturing firms, calculated as the number of high tech firms at the NUTS3 level divided by the total number of manufacturing firms at the NUTS3 level.

The logarithm of the minimum amount of total assets among all the banks with the headquarters in a given NUTS3 region.

Non-performing loans over performing loans at the NUTS3 level.

Net entry rate (new manufacturing micro firms minus the dead micro firms) divided by the total firms for each NUTS3 region, considering all the industrial sectors.

Growth of value added per person at the NUTS3 level. 
frontier, we define the price of deposit as the ratio of interest expenses and total deposits, while the price of labor is defined as the labor expenses per employee. ${ }^{13}$ Finally, total cost $\left(T C_{i t}\right)$ is the sum of interest expenses and labor costs. $M C_{i t}$ is derived from the translog cost function as $\partial \ln T C_{i t} / \partial \ln Q_{i t}$.

$$
M C_{i t}=\left(\frac{T C_{i t}}{Q_{i t}}\right) *\left(\beta_{0}+\beta_{l} \ln Q_{i t}+\beta_{2} \ln w 1_{i t}+\beta_{3} \ln w 2_{i t}+\beta_{4} t\right),
$$

where $T C_{i t}$ is total cost, $Q_{i t}$ is total loans; $w 1_{i t}$ (price of labor) and $w 2_{i t}$ (price of deposits) are the input prices, and $t$ is the time trend. We substitute $M C_{i t}$ in equation (8), where we use the local short-term interest rate on loans as the price of loans. ${ }^{14}$

\section{Data Sources}

The dataset we build borrows from five different sources: the Bank of Italy, the Italian Banking Association (ABI), the Italian National Institute of Statistics (ISTAT), Eurostat and Movimpresa. The latter provides data on birth/death rates for businesses run by InfoCamere on behalf of Unioncamere in the archives of all the Italian Chambers of Commerce. The Bank of Italy provides historical information on bank branches in 1936, 1987 and for the sample period 19982013. The Italian Banking Association provides the remainder of the bank-level variables. Eurostat collects data on patent applications to the EPO by NUTS3 regions. Finally, ISTAT and Movimpresa collect data on local market structure and the demography of industrial firms. The result is a data set that covers 103 Italian NUTS3 regions over the period 1998-2013, with the addition of the historical share of small, cooperative banks in 1936 and 1987. ${ }^{15}$ Table 2 reports the descriptives statistics of all the variables included in equation $6 \mathrm{~b}$.

Before we proceed to our empirical analysis, it is good to take stock of the coverage of our data. Table 2 shows that SEs represent almost $85 \%$ of firms in manufacturing $\left(M S_{i t}^{S E, m i c r o}\right)$. Moreover, more than half of these firms are sole proprietorships $\left(M S_{i t}^{S E, s p}\right)$. Meanwhile, at present small, local banks are indeed small and present throughout Italy, as is clear from the low mean and standard deviation for $\lambda$, the minimum size of small banks in a local market. Overall, the Italian banking sector is of a relatively modest size, consisting of $60 \%$ mutual and cooperative banks and with total financial assets equal to 2.6 times GDP in 2014, compared to 3.1 times GDP in Germany, and 4.0 in France (Bank of Italy, 2014).

\footnotetext{
fixed effects. More details are available upon request.

${ }^{13}$ Whereas the former varies from region to region, the latter cannot, since labor expenses for the financial sector are only available at the national level. Note however, that our regional fixed effects can absorb regional differences in labor expenses.

${ }^{14}$ Note that the data on interest rates are available at the NUTS2 level for the period under investigation.

${ }^{15}$ The start of our sample period is restricted by the availability of interest rates on loans and deposits as of 1998.
} 
Table 2-: Descriptive statistics

\begin{tabular}{|c|c|c|c|c|c|c|}
\hline \multirow[b]{2}{*}{ Variables } & \multirow[b]{2}{*}{ Mean } & \multirow[b]{2}{*}{ SD } & \multicolumn{2}{|c|}{ MS36 $<$ median } & \multicolumn{2}{|c|}{ MS36 $>$ median } \\
\hline & & & Mean & SD & Mean & SD \\
\hline & (1) & (2) & (3) & (4) & (5) & (6) \\
\hline$M S^{S E, \text { micro }}$ & 0.847 & 0.060 & 0.838 & 0.056 & 0.853 & 0.063 \\
\hline$M S^{S E, s p}$ & 0.550 & 0.092 & 0.534 & 0.092 & 0.569 & 0.109 \\
\hline$M S^{S E, h i g h-t e c h}$ & 0.110 & 0.034 & 0.111 & 0.034 & 0.110 & 0.036 \\
\hline Patents / Pop & 3.469 & 1.352 & 3.735 & 1.278 & 3.237 & 1.372 \\
\hline$M S^{S B, 1936}$ & 0.212 & 0.184 & 0.061 & 0.056 & 0.344 & 0.151 \\
\hline$M S^{S B, 1987}$ & 0.105 & 0.139 & 0.059 & 0.088 & 0.145 & 0.162 \\
\hline$\theta_{1}$ & 0.589 & 0.170 & 0.573 & 0.205 & 0.604 & 0.148 \\
\hline$\theta_{2}$ & 0.603 & 0.176 & 0.588 & 0.206 & 0.617 & 0.145 \\
\hline$v$ & 0.151 & 2.603 & 0.219 & 2.279 & 0.110 & 2.448 \\
\hline$R$ & 0.591 & 0.184 & 0.604 & 0.192 & 0.562 & 0.185 \\
\hline$N$ & 0.223 & 0.076 & 0.233 & 0.068 & 0.218 & 0.072 \\
\hline$\lambda$ & 4.439 & 1.810 & 4.167 & 2.142 & 4.628 & 1.409 \\
\hline$M$ & 0.023 & 0.020 & 0.019 & 0.017 & 0.024 & 0.020 \\
\hline$Y$ & 0.006 & 0.014 & 0.006 & 0.013 & 0.007 & 0.016 \\
\hline$\eta$ & 0.021 & 0.036 & 0.024 & 0.037 & 0.022 & 0.036 \\
\hline Pop & 6.023 & 0.708 & 6.059 & 0.818 & 5.992 & 0.593 \\
\hline Area & 0.884 & 0.635 & 0.923 & 0.642 & 0.849 & 0.625 \\
\hline
\end{tabular}

Note: $M S^{S E \text {, micro }}$ market share of micro manufacturing firms: $M S^{S E, s p}$ : market share of sole proprietorship manufacturing firms; $M S^{S E \text {, high-tech }}$ market share of sole proprietorships active in innovative sectors; Patents/Pop: logarithm of number of patents per million inhabitants; $M S^{S B, 1936}$ and $M S^{S B, 1987}$ : market share of cooperative banks in 1936 and 1987; $\theta_{1}$ and $\theta_{2}$ : market share of large and medium-sized banks with over EUR9 billion in assets, based on their share in the total number of banks' branches (low flexibility state), using either NUTS3-level data $\left(\theta_{1}\right)$ or branch-level data $\left(\theta_{2}\right)$, source: Bank of Italy; $v$ : the ratio of the growth of employees for each location and size of firms to the total growth of the employees at the NUTS3 level (environmental variable), source: ISTAT Asia database; $\eta$ : growth rate of the value added per person, source: ISTAT and Istituto Guglielmo Tagliacarne; N: market share of high-tech firms (rents): source, ISTAT; $\lambda$ : the logarithm of the minimum size of a bank in a NUTS3 region (Monitoring), source: Association of Italian banks (ABI); M: non-performing loans over performing loans (Monitoring cost), source: Bank of Italy; $Y$ : net entry rate (new manufacturing micro firms minus the dead micro firms) divided by the total firms (successful project payoff), source: ISTAT Asia database; $R$ : monopoly market power in the loan markets (Lerner Index), sources: Bank of Italy, ISTAT; Pop: the logarithm of the population in each NUTS3 region, source: ISTAT; Area: the logarithm of $\mathrm{km}^{2}$ per NUTS3 region.

Table 2 also shows that the historical market share of small and local banks was in fact rather low, at 20\% in 1936 and 11\% in 1987, respectively. However, the presence of local banks was geographically uneven as indicated by the differences in mean values in columns (3) and (5). With the liberalization to the opening of branches in 1987, the number of branches of medium and large banks, $\theta_{1}$ and $\theta_{2}$, increased. The main difference between the two measures of $\theta$ is that whereas the former is calculated using NUTS3-level data $\left(\theta_{1}\right)$ the latter is based on branch-level data $\left(\theta_{2}\right)$, and therefore also includes opened and/or closed during the year. As a consequence their average market share is equal to $60 \%$ on average for the period from 1998 to 2013. Nevertheless, market power is relatively high in most markets, as evidenced by the high values (and low medians) for $R$, the Lerner index. Meanwhile, Table 2 captures the large differences in 
NUTS3 regions' structural and economic characteristics, with high standard deviations for net entry rates $(Y)$, employee growth $(v)$ and non-performing loans $(M)$. Finally, Italian NUTS3 regions vary considerably in their size (Area) and populations density (Pop).

\section{Empirical Results}

We first study the straightforward, causal impact of the historical local banking structure on the market share of SEs. Next, we examine the various channels that have strengthened or weakened this impact. Subsequently, we investigate whether its indeed the market share of SEs that is explained, and not the share of innovative firms, that happen to be small. Finally, we present a simple counterfactual analysis to demonstrate how the historical local banking structure has shaped Italy's industrial structure as we know it today.

\section{A. Measuring the causal impact}

We start by analyzing the causal impact of the local banking structure in 1936 and 1987 on the market share of SEs for the period from 1998 to 2013. We adopt a geographical perspective, contrary to the studies that have devoted their attention to the effect of bank size or lending technologies on the access to credit of small businesses (Alessandrini, Presbitero and Zazzaro, 2009; Bartoli et al., 2013; Berger et al., 2005; Berger and Black, 2011; Ferri and Murro, 2015).

Columns (1) and (2) of Table 3 report the results of estimating equation (6a), where the key righthand-side variables are $M S^{S B, 1936}$ and $M S^{S B, 1987}$, respectively. We include time fixed effects to account for all unobservable time-variant NUTS3-level specific factors. We also control for the population density and geographical size of each NUTS3 region. Notably, we find a positive and significant impact of both $M S^{S B, 1936}$ and $M S^{S B, 1987}$ on the market share of SEs in each NUTS3 region.

As a robustness test, we replicate this straightforward causal test in Table 4, where the dependent variable is now the market share of sole proprietorship manufacturing firms. For those firms the impact of the market share of small banks in 1936 and 1987 is even stronger. In particular, a one standard deviation increase of $M S^{S B, 1936}$ is associated with a $3 \%\left(0.184^{*} 0.151\right)$ increase of the market share of sole proprietorship manufacturing firms, while a one standard deviation increase of $M S^{S B, 1987}$ is associated with a $2 \%\left(0.139^{*} 0.132\right)$ increase of the market share of sole proprietorship manufacturing firms. ${ }^{16}$ Furthermore, whereas we can so far explain between $20.0 \%\left(M S^{S B, 1987}\right)$ and $24.0 \%\left(M S^{S B, 1936}\right)$ of total variance in the market shares of sole proprietorships, we can only explain between $8.9 \%\left(M S^{S B, 1987}\right)$ and $12.1 \%\left(M S^{S B, 1936}\right)$ of total variance in the market shares of

\footnotetext{
${ }^{16}$ In our initial estimates in columns (1) and (2) in Table 3, the comparable impact on the share of SEs is equal to $1.3 \%$ in the case of $M S^{S B, 1936}$ and almost $1 \%$ in the case of $M S^{S B, 1987}$.
} 
SEs as a whole. Meanwhile, the share of SEs is higher in larger NUTS3 regions, but lower when population density is high.

Our findings are consistent with the views of Berger, Rosen and Udell (2007) that it is the share of small banks present in a market that matters most for the access to credit of small businesses. We also find support for the views of Arthur (1986) and Krugman (1991), who argue that industry locations and agglomeration economies today are a consequence of historical 'accidents' - in this case the 1936 law - in a distant past. Indeed, when the geographical restrictions imposed by the 1936 law were imposed, the local market characteristics and industrial needs were hardly taken into account. Rather, they were the result of previous waves of bank creation and the Italian unification. Paradoxically, these geographical restrictions have indeed contributed to shaping the industrial landscape that we observe across the NUTS3 regions nowadays.

Our findings also relate to a broader palette of results commonly found in the economic geography literature. We show that the local banking market structure matters across industries, as small banks' role in financing intermediate demand and help forge inter-sectoral linkages can help explain the establishment and success of small firms in certain regions. ${ }^{17}$ Consistent with Hirschman (1858) and recent studies in economic geography (Meliciani and Savona, 2014; Raspe and Van Oort, 2006; Van Oort, 2007), we provide evidence that firms concentrate where their clients or suppliers are located as the geographical proximity and co-location of firms extends beyond the existence of urbanization externalities and can also be driven by supply relationships. Capital is a significant factor of production, contributing to profit and growth of SEs, and the allocation of its funding connects small banks and small firms in an enduring manner, especially in Italy, where bank funding is still the main source of financing available to most firms.

In the next section, we discuss the channels that either strengthen or weaken the impact of the historical existence of small banks in these local markets.

\section{B. Measuring the importance of the channels}

In columns (3) to (6) of Table 3 we have estimated equation $6 \mathrm{~b}$, exploring in detail how each of the channels we identified earlier affects the impact of historical small bank presence. Again, we use two different versions for the historical small bank market shares: $M S^{S B, 1936}$ in columns (3) and (4), and $M S^{S B, 1936}$ in columns (5) and (6). We also use our two measures for large bank presence, $\theta_{1}$ (in columns (3) and (5)) and $\theta_{2}$ (columns (4) and (6)).

From Table 3, we learn that two channels are dominant: private rents $N$ and banks' monitoring capacity $\lambda$ both lower the impact of the historical share of small banks on today's share of small firms. The latter suggests that as banks increase in size they become better at recouping the costs of monitoring activi-

\footnotetext{
${ }^{17}$ See Rosenthal and Strange (2004), Rosenthal and Strange (2006) for a discussion on this issue.
} 
ties. This implies less funding for firms that are opaque and small, including the small high-tech firms that we use as a proxy for $N$.

These findings shed light on recent policy changes by the Bank of Italy. In response to the changes recommend by the recent Banking Recovery and Resolution Directive and the Single Resolution Mechanism, it has advocated a consolidation process among cooperative banks, possibly even leading to a single cooperative banking holding company. As it stands, the small banks we focus on carry a relatively high percentage of non-performing loans, and are said to often suffer from a lack of effective internal governance. Our results suggest, however, that creating one large cooperative bank can also have its downsides: a loss of focus on lending locally and the ability to serve small enterprises.

In the current system, not all lending by small banks is done in the same manner, as becomes clear when we dive into some of the other channels. The cost of borrowing $R$, the probability of a good payoff $\eta$ and a successful project payoff $Y$, related to the profitability of borrowers: all have the expected sign in some specifications, but never consistently. Increasing the probability of success of a project reduces the asymmetric information between lenders and borrowers. As a consequence, the importance of acquiring soft information in order to provide a line of credit to a client declines as the project is likely to have a positive payoff. Therefore, the advantage attributed to small banks in managing soft information appears in this context to be less relevant in the lending decisions. This means that medium and large banks represent a valid alternative to small banks for small businesses to get funds. Meanwhile, our finding that $\eta$ and $v$ are significantly negative in half of our specifications suggests that, in a healthy economic environment the relevance of small banks for the growth of small enterprises decreases.

We find no evidence that the cost of monitoring or information acquisition $M$ and the probability of being in a low flexibility state $\theta$, because of the dominance of large banks, play a role in explaining the geographic variance in the share of small enterprises through their impact on the lasting effect of the historical small banks market share. Directly, both variables significantly affect the share of SEs, but in a positive manner. Hence, our findings corroborate what has shown before by e.g. Berger et al. (2007), Coccorese (2009) and Hannan and Prager (2009): large multi-market banks improve the lending conditions for SEs as they promote competition in retail lending through the access to low-cost wholesale funds (Park and Pennacchi, 2009).

Our results remain qualitatively similar when - in Table 4 - we consider the market share of sole proprietorship manufacturing firms instead of our broader definition of SEs used so far. Sole proprietorship manufacturing firms are usually classified as family businesses by many scholars (Astrachan and Shanker, 2003). As explained byBopaiah (1998), family-owned businesses tend to receive greater availability of credit as they are seen by lenders as having fewer moral hazard problems. Voordeckers and Steijvers (2006) find that family businesses 
Table 3-: Main Results with Market Share of SEs as dependent variable

\begin{tabular}{|c|c|c|c|c|c|c|}
\hline VARIABLES & (1) & (2) & (3) & (4) & (5) & (6) \\
\hline$M S^{S B, 1936}(\mathrm{x})$ & $\begin{array}{l}0.071^{* * *} \\
{[0.008]}\end{array}$ & & $\begin{array}{l}0.112^{* * *} \\
{[0.036]}\end{array}$ & $\begin{array}{l}0.121^{* * *} \\
{[0.037]}\end{array}$ & & \\
\hline$M S^{S B, 1987}(\mathrm{x})$ & & $\begin{array}{l}0.051^{* * *} \\
{[0.010]}\end{array}$ & & & $\begin{array}{c}0.456^{* * *} \\
{[0.069]}\end{array}$ & $\begin{array}{l}0.514^{* * *} \\
{[0.071]}\end{array}$ \\
\hline $\mathrm{x} \cdot \theta_{1}$ & & & $\begin{array}{r}0.044 \\
{[0.041]}\end{array}$ & & $\begin{array}{r}-0.041 \\
{[0.062]}\end{array}$ & \\
\hline $\mathrm{x} \cdot \theta_{2}$ & & & & $\begin{array}{r}0.050 \\
{[0.041]}\end{array}$ & & $\begin{array}{r}-0.092 \\
{[0.067]}\end{array}$ \\
\hline $\mathrm{x} \cdot \mathrm{v}$ & & & $\begin{array}{l}-0.004^{* *} \\
{[0.002]}\end{array}$ & $\begin{array}{l}-0.005^{* * *} \\
{[0.002]}\end{array}$ & $\begin{array}{r}0.000 \\
{[0.003]}\end{array}$ & $\begin{array}{r}0.000 \\
{[0.003]}\end{array}$ \\
\hline $\mathrm{x} \cdot \mathrm{R}$ & & & $\begin{array}{r}-0.018 \\
{[0.030]}\end{array}$ & $\begin{array}{r}-0.038 \\
{[0.030]}\end{array}$ & $\begin{array}{l}-0.139^{* *} \\
{[0.054]}\end{array}$ & $\begin{array}{l}-0.158^{* * *} \\
{[0.055]}\end{array}$ \\
\hline $\mathrm{x} \cdot N$ & & & $\begin{array}{l}-0.232^{* *} \\
{[0.115]}\end{array}$ & $\begin{array}{l}-0.259^{* *} \\
{[0.117]}\end{array}$ & $\begin{array}{l}-1.374^{* * *} \\
{[0.159]}\end{array}$ & $\begin{array}{l}-1.432^{* * *} \\
{[0.160]}\end{array}$ \\
\hline$x \cdot \lambda$ & & & $\begin{array}{l}-0.008^{* *} \\
{[0.004]}\end{array}$ & $\begin{array}{l}-0.007^{* *} \\
{[0.004]}\end{array}$ & $\begin{array}{l}-0.013^{* *} \\
{[0.005]}\end{array}$ & $\begin{array}{l}-0.015^{* * *} \\
{[0.005]}\end{array}$ \\
\hline $\mathrm{x} \cdot M$ & & & $\begin{array}{r}-0.042 \\
{[0.405]}\end{array}$ & $\begin{array}{r}0.020 \\
{[0.414]}\end{array}$ & $\begin{array}{r}0.856 \\
{[0.573]}\end{array}$ & $\begin{array}{c}1.161^{*} \\
{[0.605]}\end{array}$ \\
\hline$x \cdot Y$ & & & $\begin{array}{l}-1.632^{* * *} \\
{[0.375]}\end{array}$ & $\begin{array}{l}-1.764^{* * *} \\
{[0.405]}\end{array}$ & $\begin{array}{r}0.149 \\
{[0.732]}\end{array}$ & $\begin{array}{r}0.592 \\
{[0.837]}\end{array}$ \\
\hline$x \cdot \eta$ & & & $\begin{array}{r}-0.147 \\
{[0.196]}\end{array}$ & $\begin{array}{r}-0.069 \\
{[0.198]}\end{array}$ & $\begin{array}{l}-0.568^{* *} \\
{[0.272]}\end{array}$ & $\begin{array}{c}-0.558^{* *} \\
{[0.284]}\end{array}$ \\
\hline$\theta_{1}$ & & & $\begin{array}{l}0.049^{* * *} \\
{[0.009]}\end{array}$ & & $\begin{array}{l}0.058^{* * *} \\
{[0.008]}\end{array}$ & \\
\hline$\theta_{2}$ & & & & $\begin{array}{l}0.056^{* * *} \\
{[0.011]}\end{array}$ & & $\begin{array}{l}0.071^{* * *} \\
{[0.009]}\end{array}$ \\
\hline$v$ & & & $\begin{array}{l}0.002^{* * *} \\
{[0.001]}\end{array}$ & $\begin{array}{l}0.002^{* * *} \\
{[0.001]}\end{array}$ & $\begin{array}{r}0.001 \\
{[0.001]}\end{array}$ & $\begin{array}{r}0.001 \\
{[0.001]}\end{array}$ \\
\hline$R$ & & & $\begin{array}{l}-0.147^{* * *} \\
{[0.012]}\end{array}$ & $\begin{array}{l}-0.144^{* * *} \\
{[0.012]}\end{array}$ & $\begin{array}{l}-0.136^{* * *} \\
{[0.010]}\end{array}$ & $\begin{array}{l}-0.133^{* * *} \\
{[0.009]}\end{array}$ \\
\hline$N$ & & & $\begin{array}{l}-0.123^{* * *} \\
{[0.028]}\end{array}$ & $\begin{array}{l}-0.128^{* * *} \\
{[0.028]}\end{array}$ & $\begin{array}{l}-0.123^{* * *} \\
{[0.021]}\end{array}$ & $\begin{array}{l}-0.130^{* * *} \\
{[0.021]}\end{array}$ \\
\hline$\lambda$ & & & $\begin{array}{r}0.000 \\
{[0.001]}\end{array}$ & $\begin{array}{r}0.000 \\
{[0.001]}\end{array}$ & $\begin{array}{r}-0.001 \\
{[0.001]}\end{array}$ & $\begin{array}{r}-0.001 \\
{[0.001]}\end{array}$ \\
\hline$M$ & & & $\begin{array}{l}0.454^{* * *} \\
{[0.117]}\end{array}$ & $\begin{array}{l}0.368^{* * *} \\
{[0.113]}\end{array}$ & $\begin{array}{l}0.343^{* * *} \\
{[0.105]}\end{array}$ & $\begin{array}{l}0.239^{* * *} \\
{[0.095]}\end{array}$ \\
\hline Y & & & $\begin{array}{l}1.192^{* * *} \\
{[0.166]}\end{array}$ & $\begin{array}{l}1.229^{* * *} \\
{[0.187]}\end{array}$ & $\begin{array}{c}0.755^{* * *} \\
{[0.161]}\end{array}$ & $\begin{array}{l}0.692^{* * *} \\
{[0.168]}\end{array}$ \\
\hline$\eta$ & & & $\begin{array}{l}0.158^{* * *} \\
{[0.063]}\end{array}$ & $\begin{array}{c}0.127^{* *} \\
{[0.063]}\end{array}$ & $\begin{array}{c}0.165^{* * *} \\
{[0.054]}\end{array}$ & $\begin{array}{l}0.146^{* * *} \\
{[0.055]}\end{array}$ \\
\hline Pop & $\begin{array}{l}-0.018^{* * *} \\
{[0.002]}\end{array}$ & $\begin{array}{l}-0.019^{* * *} \\
{[0.002]}\end{array}$ & $\begin{array}{r}-0.003 \\
{[0.002]}\end{array}$ & $\begin{array}{r}-0.004 \\
{[0.002]}\end{array}$ & $\begin{array}{r}-0.002 \\
{[0.002]}\end{array}$ & $\begin{array}{r}-0.003 \\
{[0.002]}\end{array}$ \\
\hline Area & $\begin{array}{l}0.026^{* * *} \\
{[0.002]}\end{array}$ & $\begin{array}{l}0.022^{* * *} \\
{[0.002]}\end{array}$ & $\begin{array}{l}0.010^{* * *} \\
{[0.002]}\end{array}$ & $\begin{array}{l}0.010^{* * *} \\
{[0.002]}\end{array}$ & $\begin{array}{l}0.009^{* * *} \\
{[0.002]}\end{array}$ & $\begin{array}{l}0.008^{* * *} \\
{[0.002]}\end{array}$ \\
\hline Constant & $\begin{array}{l}0.923^{* * *} \\
{[0.014]}\end{array}$ & $\begin{array}{c}0.943^{* * *} \\
{[0.015]}\end{array}$ & $\begin{array}{l}0.914^{* * *} \\
{[0.013]}\end{array}$ & $\begin{array}{l}0.907^{* * *} \\
{[0.013]}\end{array}$ & $\begin{array}{l}0.912^{* * *} \\
{[0.013]}\end{array}$ & $\begin{array}{l}0.904^{* * * *} \\
{[0.013]}\end{array}$ \\
\hline Observations & 1,648 & 1,648 & 1,648 & 1,545 & 1,648 & 1,545 \\
\hline R-squared & 0.121 & 0.089 & 0.411 & 0.409 & 0.427 & 0.428 \\
\hline Year fixed effects & YES & YES & YES & YES & YES & YES \\
\hline
\end{tabular}


Table 4-: Robustness Test: Market share of Sole Proprietorship Manufacturing Firms \& Channels

\begin{tabular}{|c|c|c|c|c|c|c|}
\hline VARIABLES & (1) & (2) & (3) & (4) & (5) & (6) \\
\hline$M S^{S B, 1936}(\mathrm{x})$ & $\begin{array}{l}0.151^{* * *} \\
{[0.013]}\end{array}$ & & $\begin{array}{l}0.183^{* * *} \\
{[0.060]}\end{array}$ & $\begin{array}{l}0.184^{* * *} \\
{[0.060]}\end{array}$ & & \\
\hline$M S^{S B, 1987}(\mathrm{x})$ & & $\begin{array}{l}0.132^{* * *} \\
{[0.017]}\end{array}$ & & & $\begin{array}{l}0.682^{* * *} \\
{[0.115]}\end{array}$ & $\begin{array}{l}0.723^{* * * *} \\
{[0.120]}\end{array}$ \\
\hline $\mathrm{x} \cdot \theta_{1}$ & & & $\begin{array}{c}0.116^{* *} \\
{[0.059]}\end{array}$ & & $\begin{array}{c}0.190^{* *} \\
{[0.091]}\end{array}$ & \\
\hline $\mathrm{x} \cdot \theta_{2}$ & & & & $\begin{array}{c}0.136^{* *} \\
{[0.057]}\end{array}$ & & $\begin{array}{r}0.146 \\
{[0.093]}\end{array}$ \\
\hline$x \cdot v$ & & & $\begin{array}{l}-0.009^{* * *} \\
{[0.003]}\end{array}$ & $\begin{array}{l}-0.010^{* * *} \\
{[0.003]}\end{array}$ & $\begin{array}{r}0.004 \\
{[0.006]}\end{array}$ & $\begin{array}{r}0.003 \\
{[0.006]}\end{array}$ \\
\hline $\mathrm{x} \cdot \mathrm{R}$ & & & $\begin{array}{l}-0.167^{* * *} \\
{[0.049]}\end{array}$ & $\begin{array}{l}-0.190^{* * *} \\
{[0.050]}\end{array}$ & $\begin{array}{l}-0.210^{* *} \\
{[0.085]}\end{array}$ & $\begin{array}{l}-0.235^{* * * *} \\
{[0.087]}\end{array}$ \\
\hline $\mathrm{x} \cdot \mathrm{N}$ & & & $\begin{array}{r}-0.134 \\
{[0.170]}\end{array}$ & $\begin{array}{r}-0.171 \\
{[0.173]}\end{array}$ & $\begin{array}{l}-2.520^{* * * *} \\
{[0.278]}\end{array}$ & $\begin{array}{l}-2.522^{* * *} \\
{[0.281]}\end{array}$ \\
\hline$x \cdot \lambda$ & & & $\begin{array}{l}-0.009^{* *} \\
{[0.005]}\end{array}$ & $\begin{array}{c}-0.009^{*} \\
{[0.005]}\end{array}$ & $\begin{array}{c}-0.016^{*} \\
{[0.009]}\end{array}$ & $\begin{array}{c}-0.017^{*} \\
{[0.009]}\end{array}$ \\
\hline $\mathrm{x} \cdot M$ & & & $\begin{array}{r}0.425 \\
{[0.714]}\end{array}$ & $\begin{array}{r}0.536 \\
{[0.723]}\end{array}$ & $\begin{array}{r}0.225 \\
{[0.894]}\end{array}$ & $\begin{array}{r}0.410 \\
{[0.939]}\end{array}$ \\
\hline $\mathrm{x} \cdot \mathrm{Y}$ & & & $\begin{array}{l}-2.405^{* * *} \\
{[0.659]}\end{array}$ & $\begin{array}{l}-2.398^{* * *} \\
{[0.695]}\end{array}$ & $\begin{array}{r}0.285 \\
{[1.179]}\end{array}$ & $\begin{array}{r}1.200 \\
{[1.265]}\end{array}$ \\
\hline$x \cdot \eta$ & & & $\begin{array}{r}0.237 \\
{[0.302]}\end{array}$ & $\begin{array}{r}0.325 \\
{[0.304]}\end{array}$ & $\begin{array}{r}-0.686 \\
{[0.455]}\end{array}$ & $\begin{array}{c}-0.793^{*} \\
{[0.449]}\end{array}$ \\
\hline$\theta_{1}$ & & & $\begin{array}{l}0.041^{* * *} \\
{[0.013]}\end{array}$ & & $\begin{array}{l}0.046^{* * *} \\
{[0.011]}\end{array}$ & \\
\hline$\theta_{2}$ & & & & & & $\begin{array}{l}0.062^{* * *} \\
{[0.013]}\end{array}$ \\
\hline$v$ & & & $\begin{array}{l}0.003^{* * *} \\
{[0.001]}\end{array}$ & $\begin{array}{l}0.003^{* * *} \\
{[0.001]}\end{array}$ & $\begin{array}{r}0.000 \\
{[0.001]}\end{array}$ & $\begin{array}{r}0.000 \\
{[0.001]}\end{array}$ \\
\hline$R$ & & & $\begin{array}{l}-0.247^{* * *} \\
{[0.018]}\end{array}$ & $\begin{array}{l}-0.241^{* * *} \\
{[0.019]}\end{array}$ & $\begin{array}{l}-0.262^{* * *} \\
{[0.016]}\end{array}$ & $\begin{array}{l}-0.257^{* * * *} \\
{[0.017]}\end{array}$ \\
\hline$N$ & & & $\begin{array}{l}-0.272^{* * *} \\
{[0.038]}\end{array}$ & $\begin{array}{l}-0.278^{* * *} \\
{[0.039]}\end{array}$ & $\begin{array}{l}-0.205^{* * *} \\
{[0.031]}\end{array}$ & $\begin{array}{l}-0.219^{* * *} \\
{[0.031]}\end{array}$ \\
\hline$\lambda$ & & & $\begin{array}{r}0.000 \\
{[0.001]}\end{array}$ & $\begin{array}{r}0.000 \\
{[0.001]}\end{array}$ & $\begin{array}{r}-0.001 \\
{[0.001]}\end{array}$ & $\begin{array}{r}-0.001 \\
{[0.001]}\end{array}$ \\
\hline$M$ & & & $\begin{array}{l}0.551^{* * *} \\
{[0.191]}\end{array}$ & $\begin{array}{c}0.387^{* *} \\
{[0.180]}\end{array}$ & $\begin{array}{l}0.564^{* * *} \\
{[0.195]}\end{array}$ & $\begin{array}{c}0.403^{* *} \\
{[0.179]}\end{array}$ \\
\hline$Y$ & & & $\begin{array}{l}1.609^{* * *} \\
{[0.289]}\end{array}$ & $\begin{array}{l}1.575^{* * *} \\
{[0.314]}\end{array}$ & $\begin{array}{l}0.962^{* * *} \\
{[0.287]}\end{array}$ & $\begin{array}{l}0.793^{* * *} \\
{[0.294]}\end{array}$ \\
\hline$\eta$ & & & $\begin{array}{r}0.111 \\
{[0.093]}\end{array}$ & $\begin{array}{r}0.083 \\
{[0.093]}\end{array}$ & $\begin{array}{l}0.213^{* * *} \\
{[0.085]}\end{array}$ & $\begin{array}{l}0.208^{* * * *} \\
{[0.085]}\end{array}$ \\
\hline Pop & $\begin{array}{l}-0.032^{* * *} \\
{[0.003]}\end{array}$ & $\begin{array}{l}-0.035^{* * *} \\
{[0.003]}\end{array}$ & $\begin{array}{r}0.000 \\
{[0.004]}\end{array}$ & $\begin{array}{r}-0.003 \\
{[0.004]}\end{array}$ & $\begin{array}{r}0.000 \\
{[0.004]}\end{array}$ & $\begin{array}{r}-0.002 \\
{[0.004]}\end{array}$ \\
\hline Area & $\begin{array}{l}0.050^{* * *} \\
{[0.003]}\end{array}$ & $\begin{array}{l}0.042^{* * *} \\
{[0.004]}\end{array}$ & $\begin{array}{l}0.022^{* * *} \\
{[0.003]}\end{array}$ & $\begin{array}{l}0.021^{* * *} \\
{[0.004]}\end{array}$ & $\begin{array}{l}0.018^{* * *} \\
{[0.003]}\end{array}$ & $\begin{array}{l}0.018^{* * *} \\
{[0.004]}\end{array}$ \\
\hline Constant & $\begin{array}{l}0.716^{* * *} \\
{[0.024]}\end{array}$ & $\begin{array}{l}0.758^{* * *} \\
{[0.024]}\end{array}$ & $\begin{array}{c}0.714^{* * *} \\
{[0.022]}\end{array}$ & $\begin{array}{l}0.707^{* * *} \\
{[0.022]}\end{array}$ & $\begin{array}{l}0.720^{* * * *} \\
{[0.021]}\end{array}$ & $\begin{array}{l}0.710^{* * * *} \\
{[0.021]}\end{array}$ \\
\hline Observations & 1,648 & 1,648 & 1,648 & 1,545 & 1,648 & 1,545 \\
\hline R-squared & 0.240 & 0.200 & 0.507 & 0.500 & 0.514 & 0.509 \\
\hline Year fixed effects & YES & YES & YES & YES & YES & YES \\
\hline
\end{tabular}


offer a higher degree of collateral/commitment protection only when there is a low amount of banking competition. This could explain why the interaction of $M S^{S B, 1936}$ and $M S^{S B, 1987}$ with $\theta 1$ is significantly positive for sole proprietorship manufacturing firms. However, Bopaiah (1998) find that family firms do not benefit from lower interest rates. Indeed, as banks experience an increase in their monopoly market power, the joint effect of the cost of borrowing $R$ and $M S^{S B, 1936}$ and $M S^{S B, 1987}$ is negatively and significantly related to the market share of sole proprietorship manufacturing firms.

\section{Small and opaque, or simply innovative?}

In our analysis so far, we have consistently made the case that the key distinguishing feature that sets small enterprises apart from the rest is, quite simply, their size. As a result of their small size, SEs are opaque, which means that a different lending strategy, aimed more at monitoring, is required to successfully lend to them, or so the argument goes. In this subsection we address a possible confounding factor: small enterprises can be opaque because of their size, but also because they tend to invest in innovative projects that are difficult to monitor and uncertain in their outcomes. Consequently, innovative firms are likely to suffer from limited access to credit compared to less innovative firms, and small firms are in this position because they are more innovative than their large counterparts, and not because of their size.

For this additional analysis, we therefore employ two different measures of innovation at the NUTS3 level: the number of sole proprietorships active in innovative sectors divided by the total number of sole proprietorships $\left(M S^{S E, h i g h-t e c h}\right)$; and the logarithm of the number of patents per million inhabitants at the NUTS3 level (Patents / Pop).

While Patents/Pop is a conventional innovation statistic in the literature, $M S^{S E, h i g h-t e c h}$ is related to the industrial composition at the NUTS3 level. For

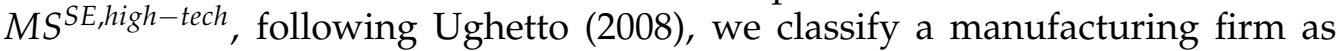
high-tech if it belongs to the following sectors: chemicals and drugs (Ateco 24), mechanical machinery (Ateco 29), computer equipment (Ateco 30), electronic components and machinery (Ateco 31), communication equipment (Ateco 32), medical, optical, and precision equipment (Ateco 33), and transportation equipment (Ateco 34-35). This criterium is applied for the years 1998 and 2007, taking in account the differences in terms of classification in the economic sector over the time period analysed ${ }^{18}$. After 2007, a new classification of economic activities was introduced, Ateco 2007, which differs from the previous one. Consequently, for the years 2008-2013 we use different codes which, however, refer to similar economic activities: Ateco 20, Ateco 28, Ateco 33, Ateco 26, Ateco 27 and Ateco 30.

\footnotetext{
${ }^{18}$ We specifically exclude code 35.2, which presents a difference between two classifications, Ateco 1991 and Ateco 2002.
} 
Table 5-: Opacity. Dependent Variable: Market Share of Sole Proprietorship and High-Tech Manufacturing Firms, and Numbers of Patents per Person

\begin{tabular}{|c|c|c|c|c|}
\hline VARIABLES & $\begin{array}{r}(1) \\
M S^{S E, h i g h-t e c h}\end{array}$ & $\begin{array}{r}(2) \\
\text { Patents / Pop }(+)\end{array}$ & $M S^{S E, h i g h-t e c h}$ & $\begin{array}{r}(4) \\
\text { Patents / Pop }(=)\end{array}$ \\
\hline$M S^{S B, 1936}$ & $\begin{array}{l}-0.015^{* * *} \\
{[0.004]}\end{array}$ & $\begin{array}{l}-1.901^{* * *} \\
{[0.198]}\end{array}$ & & \\
\hline$M S^{S B, 1987}$ & & & $\begin{array}{l}-0.010^{* *} \\
{[0.005]}\end{array}$ & $\begin{array}{l}-2.074^{* * *} \\
{[0.215]}\end{array}$ \\
\hline Pop & $\begin{array}{r}-0.001 \\
{[0.001]}\end{array}$ & $\begin{array}{l}0.551^{* * *} \\
{[0.049]}\end{array}$ & $\begin{array}{r}0.000 \\
{[0.001]}\end{array}$ & $\begin{array}{l}0.600^{* * *} \\
{[0.054]}\end{array}$ \\
\hline Area & $\begin{array}{l}-0.010^{* * *} \\
{[0.002]}\end{array}$ & $\begin{array}{l}-0.566^{* * *} \\
{[0.045]}\end{array}$ & $\begin{array}{l}-0.010^{* * *} \\
{[0.002]}\end{array}$ & $\begin{array}{l}-0.464^{* * *} \\
{[0.049]}\end{array}$ \\
\hline Constant & $\begin{array}{l}0.124^{* * * *} \\
{[0.008]}\end{array}$ & $\begin{array}{l}0.912^{* * *} \\
{[0.298]}\end{array}$ & $\begin{array}{l}0.120^{* * *} \\
{[0.008]}\end{array}$ & $\begin{array}{r}0.343 \\
{[0.321]}\end{array}$ \\
\hline Observations & 1,545 & 1,442 & 1,545 & 1,442 \\
\hline R-squared & 0.163 & 0.191 & 0.158 & 0.169 \\
\hline Year fixed effects & YES & YES & YES & YES \\
\hline
\end{tabular}

In Table 5, we repeat our initial simple causality test. From the Table, we can infer that our findings so far can indeed be attributed to the size of SEs: whereas $M S^{S B, 1936}$ and $M S^{S B, 1987}$ now both have a significantly negative effect on both the share of high-tech firms and the innovativeness of the different regions.

\section{What would Italy look like without small local banks?}

To finalize our empirical analysis, we consider the counterfactual, and ask what Italy would look like without small local banks. Often, the economic geography of Italy is considered only as a juxtaposition between the north and the south. The analysis presented here demonstrates that this is a clear oversimplification. From Figure 1b, we already observed that whereas the presence of small enterprises is indeed notable in many regions in the south, the same can be said for the north.

In Figure 2, we show what Italy would look like without the banking law we made use of in our identification strategy. To do so, we take the estimated coefficients in columns (3) and (5) of 3, and use them to predict the share of SEs in each region, with one noted difference: instead of using the actual value of the historical share of small banks, we replace it with its median historical - as if there had been no historical difference between the presence of small banks. Of course, this is an oversimplification, but the results, depicted in Figures $2 \mathrm{a}$ and $2 \mathrm{~b}$, respectively, serve to illustrate what might have been without the historical diversity in the local banking markets.

From the figures, we observe that the presence of SEs would have indeed been much more equal across the nation. Notably, the dominance of SEs in the centre 
Figure 2. : Counterfactual Analysis

(a) Share of Micro Firms-1936

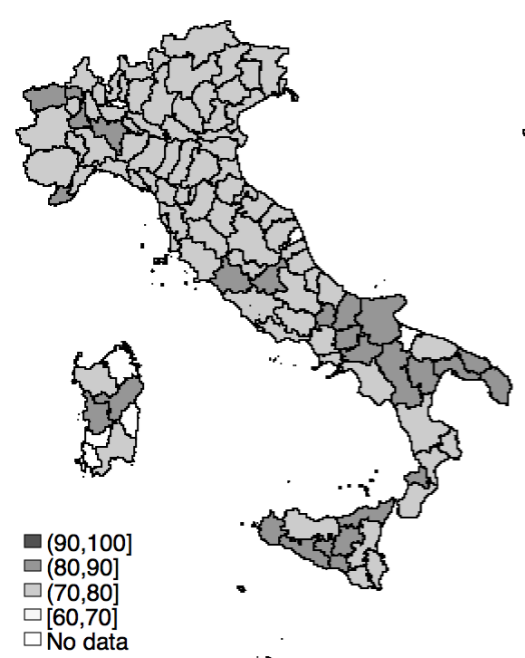

(b) Share of Micro Firms-1987

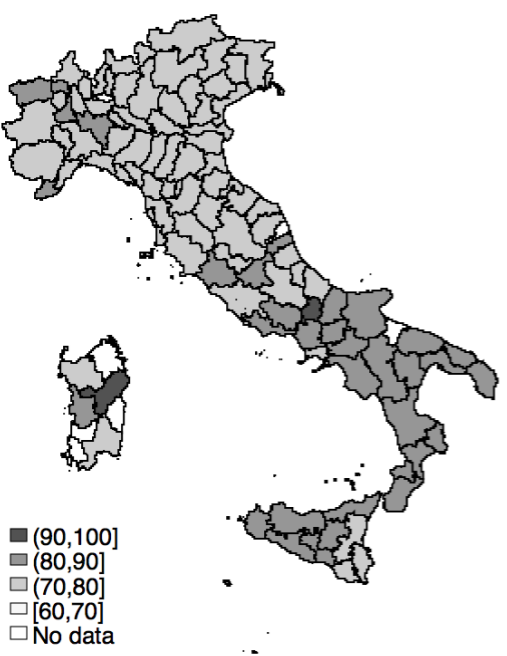

Note: The share of SEs is estimated by substituting in equation 7 the coefficient that we have estimated in Table 3 over the period 1998-2013. We then substitute in equation 7 the median value of $M S^{S B, 1936}$ and $M S^{S B, 1987}$.

of the country is gone once we get rid of the underlying variance in the historical share of small local banks. Generally speaking, the south would in fact have in relative terms - a slightly higher concentration in SEs than we find in practice. However despite the economic boom in the fifties and sixties, and the increase of economic and social inequalities between the north and the south of Italy, the industrial economic structure of the entire country would have been much more homogenous.

Would these changes to the industrial landscape be important from an economic viewpoint? To answer this question, we examine the impact of the market share of SEs and medium-large firms on the productivity of manufacturing at the NUTS3 level. We include time and NUTS3-fixed effects to account for unobservable time-variant and regional factors. As a measure of manufacturing productivity, we use the logarithm of the value added of manufacturing divided by the number of employees in manufacturing s (ManfVA). ${ }^{19}$

Table 6 shows the results of this analysis. The market share of SEs, $M S_{i t}^{\text {SE,micro, }}$, is positively and significantly related to ManfVA. Meanwhile, the share of medium-large firms, $M S_{i t}^{M L}$, is negatively and significantly related to ManfVA. From an economic viewpoint, a one standard deviation increase of $M S_{i t}^{S E \text {,micro }}$ is associated with a $45 \%$ increase of $M a n f V A$, while a one standard deviation

${ }^{19}$ ManfVA has a mean value equal to 140.8255 and standard deviation of 272.9634 . 
increase of $M S_{i t}^{M L} 20$ is associated with a $1 \%$ decrease of ManfVA.

Table 6-: Value Added of the Manufacturing Industry and the Market Share of SEs and Medium - LargeFirms

\begin{tabular}{lcc}
\hline & ManfVA & ManfVA \\
\hline$M S_{i t}^{S E, \text { micro }}$ & $7.020^{* * *}$ & \\
$M S_{i t}^{M L}$ & {$[1.516]$} & \\
& & $-28.480^{* * *}$ \\
Pop & & {$[8.327]$} \\
& 0.604 & $0.632^{* *}$ \\
Constant & {$[0.363]$} & {$[0.222]$} \\
& -3.746 & $2.749^{*}$ \\
Observations & {$[3.194]$} & {$[1.231]$} \\
R-squared & 1,648 & 1,648 \\
NUTS3 region fixed effects & 0.284 & 0.357 \\
Year fixed effects & Yes & Yes \\
\hline
\end{tabular}

Note: ManfVA is the logarithm of manufacturing value added per number of employees of the manufacturing sector at the NUTS3 level. $M S_{i t}^{S E, \text { micro }}$ is the market share of small manufacturing firms with less than 10 employees. $M S_{i t}^{M L}$ is the market share of medium-large manufacturing firms with more than 50 employees.

Summing up, our analysis in this final part of our results section suggests that preserving the diversity in local banking markets, in business models and the size of banks, can have important benefits.

\section{Conclusion}

This paper investigates to what extent the configuration of manufacturing and specifically the geographical distribution of small enterprises is determined by the market share of small banks. We show that without the historical presence of small, local banks, Italy's manufacturing landscape would look very differently. Small banks can help small enterprises flourish, as long as they have sufficient monitoring capacity and the firms they lend to are not able to capture too much in rents.

Using a detailed database on firms and banks for the Italian market from 19982013, we paint a simple, but very powerful picture: we show that the structure of the Italian banking system in 1936 - before the liberalization process in the early 1990s - is an important factor that has shaped the current size and distribution of small enterprises in local markets.

Policy makers should be aware that a further consolidation of banking sectors and increases in the sizes of banks changes the way the latter do business in ways that can harm the growth of small enterprises and sole proprietorship firms.

${ }^{20}$ The mean is 0.019 and mean 0.011 
The result is a manufacturing eco-system that is less diverse, both locally - with the presence of fewer small firms - and across the country. The resulting loss in manufacturing resilience and - possibly - productivity provide an important counter argument to possible gains in financial stability that result from the same process.

\section{References}

Alessandrini, P., A. F. Presbitero, and A. Zazzaro. 2009. "Banks, distances and firms' financing constraints." Review of Finance, 13(2): 261-307.

Alessandrini, P., A. F. Presbitero, and A. Zazzaro. 2010. “Bank size or distance: what hampers innovation adoption by SMEs?" Journal of Economic Geography, 10(6): 845-881.

Arthur, W Brian. 1986. "Industry location patterns and the importance of history." 49-67. Michigan, USA:Michigan University Press.

Astrachan, J. H., and M. C. Shanker. 2003. "Family Businesses' Contribution to the U.S. Economy: A Closer Look." Family Business Review, XVI (3): 211-219.

Bank of Italy. 2014. "Annual Report." Bank of Italy Annual Report, www.bancaditalia.it.

Bartoli, F., G. Ferri, P. Murro, and Z. Rotondi. 2013. "SME financing and the choice of lending technology in Italy: Complementarity or substitutability?" Journal of Banking $\mathcal{E}$ Finance, 37(12): 5476-5485.

Beck, Thorsten, Asli Demirguc-Kunt, and Ross Levine. 2005. "SMEs, growth, and poverty: cross-country evidence." Journal of Economic Growth, 10(3): 199229.

Beck, Thorsten, Asli Demirgüç-Kunt, and Vojislav Maksimovic. 2008. "Financing patterns around the world: Are small firms different?" Journal of Financial Economics, 89(3): 467-487.

Benfratello, L., F. Schiantarelli, and A. Sembenelli. 2008. "Banks and innovation: Microeconometric evidence on Italian firms." Journal of Financial Economics, 90(2): 197-217.

Berger, A. N., A. A. Dick, L. G. Goldberg, and L. J. White. 2007. “Competition from large, multimarket firms and the performance of small, single-market firms: Evidence from the banking industry." Journal of Money, Credit and Banking, 39(2-3): 331-368.

Berger, A. N, and G. F. Udell. 2002. "Small business credit availability and relationship lending: The importance of bank organisational structure." Economic Journal, 112(477): F32-F53. 
Berger, A. N, and G. F. Udell. 2006. "A more complete conceptual framework for SME finance." Journal of Banking E Finance, 30(11): 2945-2966.

Berger, A. N., and L. K. Black. 2011. "Bank size, lending technologies, and small business finance." Journal of Banking and Finance, 35: 724735.

Berger, A. N., N. H. Miller, M. A. Petersen, R. G. Rajan, and J. C. Stein. 2005. "Does function follow organizational form? Evidence from the lending practices of large and small banks." Journal of Financial Economics, 76(2): 237-269.

Berger, A. N., R. J. Rosen, and G. F. Udell. 2007. "Does market size structure affect competition? The case of small business lending." Journal of Banking $\mathcal{E}$ Finance, 31(1): 11-33.

Boot, A.W.A., and A. V. Thakor. 1997. "Financial system architecture." Review of Financial studies, 10(3): 693-733.

Bopaiah, C. 1998. "Availability of Credit to Family Businesses." Small Business Economics, 11(1): 11-75.

Coccorese, P. 2009. "Market power in local banking monopolies." Journal of Banking $\mathcal{E}$ Finance, 33(7): 1196-1210.

Cole, Rebel A., Lawrence G. Goldberg, and Lawrence J. White. 2004. “Cookie Cutter vs. Character: The Micro Structure of Small Business Lending by Large and Small Banks." Journal of Financial and Quantitative Analysis, 39(2): 227-251.

De la Torre, Augusto, María Soledad Martínez Pería, and Sergio L Schmukler. 2010. "Bank involvement with SMEs: Beyond relationship lending." Journal of Banking \& Finance, 34(9): 2280-2293.

Edwards, C. D. 1955. "Conglomerate bigness as a source of power." In Business Concentration and Price Policy. Princeton, NJ: Princeton University Press:National Bureau of Economic Research.

Ferri, Giovanni, and Pierluigi Murro. 2015. "Do firm-bank 'odd couples' exacerbate credit rationing?” Journal of Financial Intermediation, 24(2): 231-251.

Giannetti, C. 2012. "Relationship lending and firm innovativeness." Journal of Empirical Finance, 19(5): 762-781.

Guiso, L., P. Sapienza, and L. Zingales. 2004. "Does local financial development matter?" Quarterly Journal of Economics, 119(3): 929-969.

Hakenes, H., I. Hasan, P. Molyneux, and R. Xie. 2015. "Small banks and local economic development." Review of Finance, 19(2): 653-683.

Hannan, T. H., and R. A. Prager. 2009. "The profitability of small singlemarket banks in an era of multi-market banking." Journal of Banking $\mathcal{E}$ Finance, 33(2): 263-271. 
Herrera, A. M., and R. Minetti. 2007. "Informed finance and technological change: evidence from credit relationships." Journal of Financial Economics, 83(1): 223-269.

Hirschman, A. O. 1858. Strategy of Economic Development. New Haven, CT and London: Yale University Press.

Keeble, David, and Sheila Walker. 1994. "New firms, small firms and dead firms: spatial patterns and determinants in the United Kingdom." Regional studies, 28(4): 411-427.

Krugman, Paul. 1991. "Increasing returns and economic geography." Journal of Political Economy, 99(3): 483-499.

Liberti, Jose M, and Atif R Mian. 2009. "Estimating the effect of hierarchies on information use." Review of Financial Studies, 22(10): 4057-4090.

Meliciani, Valentina, and Maria Savona. 2014. "The determinants of regional specialisation in business services: agglomeration economies, vertical linkages and innovation." Journal of Economic Geography, 15(2): 387-416.

Minetti, Raoul, Pierluigi Murro, and Monica Paiella. 2015. "Ownership structure, governance, and innovation." European Economic Review, 80: 165-193.

Ongena, S., G. Tümer-Alkan, and N. Westernhagen. 2012. "Creditor concentration: An empirical investigation." European Economic Review, 56(4): 830-847.

Park, K., and G. Pennacchi. 2009. "Harming depositors and helping borrowers: The disparate impact of bank consolidation." Review of Financial Studies, 22(1): 1-40.

Peek, Joe, and Eric S. Rosengren. 1995. "Small business credit availability: how important is size of lender?" Federal Reserve Bank of Boston Working Papers 95-5.

Petersen, Mitchell A., and Raghuram G. Rajan. 1994. "The Benefits of Lending Relationships: Evidence from Small Business Data." The Journal of Finance, 49(1): 3-37.

Petersen, Mitchell A., and Raghuram G. Rajan. 2002. "Does Distance Still Matter? The Information Revolution in Small Business Lending." The Journal of Finance, 57(6): 2533-2570.

Raspe, Otto, and Frank Van Oort. 2006. "The knowledge economy and urban economic growth." European Planning Studies, 14(9): 1209-1234.

Rosenthal, Stuart S., and William C. Strange. 2004. "Evidence on the nature and sources of agglomeration economies." In Handbook of Regional and Urban Economics. Vol. 4 of Handbook of Regional and Urban Economics, , ed. J. V. Henderson and J. F. Thisse, Chapter 49, 2119-2171. Elsevier. 
Rosenthal, Stuart S, and William C Strange. 2006. "The Micro-Empirics of Agglomeration Economies." In A Companion to Urban Economics. , ed. R. J. Arnott and D. P. McMillen, Chapter 1, 7-23. Oxford, UK:Blackwell Publishing Ltd.

Ughetto, E. 2008. "Does internal finance matter for R\&D? New evidence from a panel of Italian firms." Cambridge Journal of Economics, 32(6): 907-925.

Van Oort, Frank G. 2007. "Spatial and sectoral composition effects of agglomeration economies in the Netherlands." Papers in Regional Science, 86(1): 5-30.

Voordeckers, W., and T. Steijvers. 2006. "Business collateral and personal commitments in SME lending." Journal of Banking \& Finance, 30(11): 3067-3086.

\section{Appendix}

We start by rewriting equations (3a) and (3b). Solving for $\theta$, we obtain:

$$
\begin{array}{r}
\theta=\frac{E\left(R_{S}\right)-\xi \eta\left(Y-i_{S}\right)-(1-\xi) N}{\eta\left(Y-i_{S}\right)-\xi \eta\left(Y-i_{S}\right)-(1-\xi) N} \\
\theta=\frac{E\left(R_{L}\right)-N}{\gamma E\left(R_{L} \mid v=1\right)+(1-\gamma) E\left(R_{L} \mid v=0\right)-N}
\end{array}
$$

At this point remember that small, opaque borrowers below a threshold value $\bar{\theta}$ of observable quality opt for small bank financing, and borrowers above that threshold value choose large bank financing. Hence, the higher $\bar{\theta}$, the more the presence of SEs depends on the availability of small bank financing. To see how $\theta$ depends on the market share of small banks $\sigma_{s}$, we proceed by combining equations (A.1a) and (A.1b) and obtain:

$$
\begin{aligned}
\theta= & \sigma_{S}\left\{\frac{E\left(R_{S}\right)-\xi \eta\left(Y-i_{S}\right)-(1-\xi) N}{\eta\left(Y-i_{S}\right)-\xi \eta\left(Y-i_{S}\right)-(1-\xi) N}\right\}+ \\
& \left(1-\sigma_{S}\right)\left\{\frac{E\left(R_{L}\right)-N}{\gamma E\left(R_{L} \mid v=1\right)+(1-\gamma) E\left(R_{L} \mid v=0\right)-N}\right\}
\end{aligned}
$$

Therefore:

$$
\frac{\partial \theta}{\partial \sigma_{S}}=\frac{E\left(R_{S}\right)-X}{\eta\left(Y-i_{S}\right)-X}-\frac{E\left(R_{L}\right)-N}{E\left(R_{L}\right) \mid v-N}
$$

where $X=\xi \eta\left(Y-i_{S}\right)-(1-\xi) N$ and $E\left(R_{L}\right) \mid v=\gamma E\left(R_{L} \mid v=1\right)+$ $(1-\gamma) E\left(R_{L} \mid v=0\right)$.

Since $0 \leq \theta \leq 1$, we know from equation (A.1a) that $E\left(R_{S}\right) \leq \eta\left(Y-i_{S}\right)$ and from equation (A.1b) that $E\left(R_{L}\right) \leq E\left(R_{L}\right) \mid v$. Also, $\frac{\partial \theta}{\partial \sigma_{s}}$ is decreasing in $N$. 